\title{
Contingencies of Contingent Employment: Psychological Contract, Job Insecurity and Employability of Contracted Workers
}

\section{Contingencias del Empleo Contingente: Contrato Psicológico, Inseguridad en el Puesto y Empleabilidad de los Trabajadores Contratados}

\author{
Maria José Chambel and Rita Fontinha \\ University of Lisbon
}

\begin{abstract}
Drawing on psychological contract literature, the present study examines the emerging contingent employment relationships, which involve the contracted workers, the employment agency and the client organization on whose premises these employees work. This sample includes eighty-eight white-collar employees working for four Portuguese agencies. The results suggest that the perceived fulfilment of client's obligations relates positively to the perceived fulfilment of agency's obligations and that these constructs are independent of one another. Furthermore, as expected, we have found that the perception of job insecurity relates negatively to the fulfilment of agency's obligations. No relationship was found between employability and the perceived fulfilment of client's obligations. The results have implications for practitioners and future research.

Key words: contracted workers, contingent employment, psychological contract job insecurity, employability.

Resumen. Basándonos en la literatura del contrato psicológico, el presente estudio examina la emergencia de relaciones de empleo contingentes, que implican a los trabajadores contratados, la agencia de empleo y la organización cliente en cuyas instalaciones trabajan los empleados. Esta muestra incluye 88 empleados de oficina, que trabajan para cuatro agencias portuguesas. Los resultados sugieren que el cumplimiento percibido de las obligaciones del cliente se relaciona positivamente con el cumplimiento percibido de las obligaciones de la agencia y que estos constructos son independientes uno de otro. Además, como se esperaba, hemos encontrado que la percepción de inseguridad en el trabajo se relaciona negativamente con el cumplimiento de las obligaciones de la agencia. No se encontraron relaciones entre la empleabilidad y el cumplimiento percibido de obligaciones del cliente. Los resultados tienen implicaciones para la práctica y la investigación futura.

Palabras clave: trabajadores contratados, empleo contingente, contrato psicológico, inseguridad laboral, empleabilidad.
\end{abstract}

\section{Introduction}

Considering the current business dynamics involving constant and unpredictable change, organizations are forced to adapt rapidly, in terms both of the number of employees and the skills of such employees (Moorman \& Harland, 2002). The way organizations face this need for flexibility relies in outsourcing employees and skills. Employers turn to outside workers in order to achieve flexibility to respond to changes in labour demands, to handle long- or short-term projects without the commitment and costs associated with directly hired workers, and to diminish fixed labour

Correspondence on this paper should be sent to Maria José Chambel, Faculty of Psychology, University of Lisbon, Alameda da Universidade, 1649-013 Lisboa, Portugal. E-mail: mjchambel@fpce. ul.pt costs (Kalleberg, Reskin \& Hudson, 2000; Lepak, Takeuchi \& Snell, 2003). Actually one of the most relevant human resource trends has been the extraordinary growth in contingent employment arrangements since the past decade (Marler, Barringer \& Milkovich, 2002). Contingent work is an increasingly significant form of employment worldwide. It accounted for around 2.0\% of total employment involving over 9.5 million agency workers were employed in 2007 (CIETT, 2009). The contingent workforce has also grown and become increasingly important in Portugal over the past decade, counting with a current number of 233 employment agencies licensed by the national Employment and Professional Training Institute (IEFP, 2009).

Contingent employees differ from the direct-hire workers considering the tripartite employment relationship where they are involved (e.g. Feldman, 2005; Chambel \& Castanheira, 2006), meaning that they are 
hired by the employment agency to perform work at the user's firm (De Cuyper, De Jong, De Witte, Isaksson, Rigotti, \& Schalk, 2008). Contingent employment involves a wide array of arrangements that can include such different situations as on-call workers, temporary agency workers and long-term contracted workers (Theodore \& Mehta, 1999). Our research focuses on long-term contracted workers, which are characterized for working in the same client organization for a long period of time. This longer average tenure distinguishes these contracted workers from the most traditional temporary agency workers, whose average tenure is four months in Portugal (Arrowsmith, 2006). These extended tenures may relate to the development of certain projects or may be due to the relatively constant need of a service that is outside the core business of the user firm. The agency recruits and selects the workers and provides them with salaries and human resource services, which can include the bureaucratic procedures, but also training, career development opportunities, performance assessment and management. Thus, contracted workers form perceptions concerning what they receive in their exchange relationships with their agencies. Agency tries to fulfil its obligations towards the employee, engendering a retention plan that, that not only intends to retain employees but also to engage them in a way that leads to positive, productive attitudes and behaviours (Lee, 2001). The perceived fulfilment of agency's obligations relates to the building of a relationship which can be successful in terms of employee's attitudes and behavioural outcomes (e.g. CoyleShapiro, 2002; Moorman \& Harland, 2002; Chambel $\&$ Castanheira, 2006). Simultaneously these workers also form perceptions of the way in which they are treated by their client organizations (Liden, Wayne, Kraimer \& Sparrowe, 2003). Accordingly, we have focused on the idea that simultaneous dual employment relationships are possible (Druker \& Stanworth, 2004; Claes, 2005; Coyle-Shapiro \& Morrow, 2006).

We have also considered the idea that the relationship contracted employees establish with the client organization relates positively to the relationship they establish with the agency. Although being one of the most relevant theoretical frameworks in explaining employment relationships, psychological contract literature hasn't already reached the potential relationship between contracted worker's psychological contract with the agency and their psychological contract with the client organization. We have focused on this hypothetical relationship, more specifically on the idea that employees' perceived fulfilment of client organization's obligations relates positively to their perceived fulfilment of agency's obligations. On the other hand, research has also found that job insecurity and employability are important in explaining the psychological contract (e.g. Smithson \& Lewis, 2000; De Cuyper \& De Witte, 2006; De Cuyper \& De Witte, 2007;
Kluytmans \& Ott, 1999; Forrier \& Sels, 2003). However the relationship between these variables and the psychological contract fulfilment of contracted workers remains unexplored. This study will, then, focus on the possible relationship between job insecurity and contracted worker's perceived fulfilment of agency's obligations and on the hypothetical relationship between employability and client's obligations perceived fulfilment. This research will focus on these unexplored issues, which can be quite relevant for helping human resource practitioners dealing with contracted workers.

\section{Psychological Contract-Agency and Client}

Psychological contract is a construct that has been widely used as a point of reference for evaluating employment relationships, going beyond the legal contractual relations between employer and employee (Anderson \& Schalk, 1998). In line with Rousseau's (1989) conceptualization, perceived obligations and the extent to which these obligations are fulfilled represents the essence of the psychological contract. Perceived obligations set the parameters of the exchange whereas fulfilment of obligations captures behaviour within the exchange. The importance of studying psychological contract fulfilment relies on the fact that employees reciprocate (Gouldner, 1960) according to their perceptions of obligations' fulfilment (or breach) (Coyle-Shapiro \& Kessler, 2002).

Considering the tripartite relationship that contingent employment involves, one must examine the psychological contracts established with the agency that hires the contracted worker and the psychological contracts established with the client organization where $\mathrm{s} /$ he works daily. This double psychological contract has not been very discussed among contingent work research, except for the studies of Druker and Stanworth (2004), who qualitatively assessed employees psychological contract with their agency and their client organizations and Claes (2005), who investigated the content and the fulfilment or breach of organizational promises in psychological contracts from three perspectives (employee, agency and client). These studies proved the existence of dual psychological contracts (or two obligations' fulfilment perceptions) established between the employee and the agency and between the employee and the client organization. Accordingly, we anticipate that employees who formally work for an agency but are assigned to a client organization ought to be able to recognize and differentiate their psychological contracts with their two distinct organizational targets.

Hypothesis 1: Contracted workers distinguish two perceptions of fulfilment of psychological contracts, one for agency and other for client. 


\section{Client and Agency Psychological Contract Relationship}

Nevertheless, concerning the psychological contract literature, no one has ever investigated if the psychological contracts that the employee establishes with the agency and with the client organization are related. Previous research on organizational commitment showed that this attitude towards the agency related positively to this attitude towards the client (CoyleShapiro \& Morrow, 2006). It is quite plausible to hypothesize that there is a similar relationship between the perceived fulfilment of client's obligations and the perceived fulfilment of agency's obligations. The perceived fulfilment of agency's obligations is a natural dependent variable since, as Davidov (2004) stated, the only relatively stable relationship that contracted workers have is with the agency. Besides, previous research shows that the psychological contract established with the agency is stronger than the one established with the client organization (Druker \& Stanworth, 2004; Claes, 2005). Accordingly, one may suppose that psychological contract's fulfilment by the client is related to psychological contract's fulfilment by the agency. This supposition can be supported by the idea that contracted workers might perceive that, as the actual employer, the agency has the obligation of assuring that they are being well managed by the client organization where they work meaning making sure that this client is fulfilling its own obligations. If the contracted worker perceives that the client organization is fulfilling its obligations, they will consider that the agency is doing a good job by fulfilling their obligations (by placing her/him in a good client). Accordingly we hypothesize:

Hypothesis 2. The perceived fulfilment of client's obligations relates positively to the perceived fulfilment of agency's obligations.

\section{Job Insecurity}

Among the multiple definitions of job insecurity, this paper will rely on a global notion, in which job insecurity is conceived as an overall concern about the continued existence of the job as such in the future (Van Vuuren, Klandermans, Jacobson \& Hartley, 1991; De Witte, 1999). The subjective conceptualization of job insecurity concerns insecurity about the future, meaning that the employees involved do not know if they will retain their jobs or if they will be facing a layoff (De Witte, 1999). Job insecurity was found to be related to reduced job satisfaction and organizational commitment, poor well-being, and undesirable behaviours (De Witte, 1999; De Cuyper, Notelaers \& De Witte, 2009). The relationship between job insecurity and unfavourable outcomes is stronger among perma- nent workers than among temporary workers (De Cuyper \& De Witte, 2007). This is based on the assumption that permanent but not temporary workers expect their employer to guarantee job security. Job insecurity then may be a symptom of impaired quality of the employment relationship for permanent workers but not for temporary workers (De Cuyper \& De Witte, 2007).

According to Smithson and Lewis (2000), perceived job insecurity is likely to be reflected in the psychological contract. The traditional psychological contract reflects what has been termed an implicit social contract, meaning that hard work, security and reciprocity are linked (Smithson \& Lewis, 2000). If an organization fails to provide job security, when it is expected by an employee, it can be viewed as a breach of contract (King, 2000). In the case of contingent employment, one might suppose that the expectations of these employees, comparing to direct-hire permanent employees, are initially different. Psychological contracts of contingent workers tend to have more transactional entitlements, involving a specific, short-term period relationship and focusing upon monetary exchange (McLean Parks, Kidder \& Gallagher, 1998; De Cuyper \& De Witte, 2007). Accordingly, job insecurity may not breach these specific psychological contracts (De Cuyper \& De Witte, 2007), since these do not guarantee job security as a basic promise (De Cuyper \& De Witte, 2006; Sverke, Gallagher, \& Hellgren, 2000).

In the present investigation we focus on the contingent workforce, which involves the long-term contracted worker. Until now, research on job insecurity has never tried to relate with the psychological contract established between a contracted worker and his/her agency. Considering that the agency is the real employer of the individual (De Cuyper, De Jong, De Witte, Isaksson, Rigotti, \& Schalk, 2008) one might suppose that the relationship established with it will be the one with the main importance for the employee in assessing job security versus job insecurity. Even though contracted workers tend to feel insecure due to the nature of their work, working for an agency might give them an extra feeling of security, since if a project in a client organization ends, the agency could find them another project in one of its other clients. Contingent work can also give these workers an extra feeling of job security by the mere fact that they have a job, compared to the large amount of unemployed people there are. Accordingly, one might conjecture that, in contracted workers, job insecurity will be negatively related to the perceived fulfilment of agency's obligations. In line with these arguments our third hypothesis reads as follows:

Hypothesis 3. The perception of job insecurity is negatively related to the perceived fulfilment of agency's obligations. 


\section{Employability}

After approaching job insecurity as an inherent aspect of contingent employment, this discussion leads us inevitably to the emerging notion of employability which involves three components, namely, applicable know-how and skills, willingness to be mobile, and know-how of the job market (Kluytmans \& Ott, 1999). The discussion on employability is a forerunner of fundamental changes affecting labour relationships (Kluytmans \& Ott, 1999). Since lifetime employment cannot be guaranteed anymore, there is a need for a new balance (Kluytmans \& Ott, 1999). Several management scholars have suggested this idea of employability: offer people a different kind of psychological contract expecting that they will feel that a fair deal exists, so that they will not feel betrayed (Baruch, 2001). Forrier and Sels (2003) state that possibly employability represents an alternative to job security for temporary workers, implying that low employability rather than job insecurity might be problematic for temporary workers. Promoting employability is part of a new psychological contract between employer and employee, whereby both are responsible for maintaining the employment situation. On one hand individuals need to prioritize and set goals, manage change, present themselves well, network strategically, invest in continuous learning, and work well in teams. On the other hand management needs to adopt a coaching style, using listening and motivation skills to facilitate good decision making by employees (Bagshaw, 1997).

The huge heterogeneity among contracted workers might lead to different perceptions on the way they think contingent employment would value their skills and increase their value as applicants in the employment market. Employability involves a new mutual psychological contract where employers provide skilldevelopment opportunities for employees and they take advantage of those opportunities (Bagshaw, 1997). This means that employability is not only something that the worker has to struggle for individually, being strongly related to the inducements provided by the company. One might then ascertain that contracted workers' perception of employability is deeply related to their perceptions towards the benefits and development opportunities they receive. Contracted workers' employability is mainly guaranteed by the diverse learning experiences they have while they are in different client organizations. Considering that the client organization is the place where employees widen their range of career development opportunities, they might consider it somehow responsible for providing them with these opportunities. Accordingly, if the client is providing good development opportunities for the employee and being careful concerning his/her career management, s/he might consider that it has been fulfilling its obligations. We focus on the relationship between the long-term contracted worker and the client organization where s/he works and rely on the idea that the greater their perceived employability (which may include the benefits and development opportunities already mentioned), the more they perceive that the client has been fulfilling its obligations towards them. Therefore we propose:

Hypothesis 4. The perception of employability relates positively to the perceived fulfilment of client's obligations.

\section{Method}

\section{Procedure}

During spring 2008 we contacted four agencies that provide services to several client organizations. These client organizations have been active in the financial and information technologies sectors. Human resource managers from these agencies were interviewed by us, in order to assess if the management of the contracted workers was shared by the agencies and the client organizations. In these interviews managers were asked how they recruit the candidate for the client organization; if they try to maintain the workers in the same client; what kind of training opportunities they give them; how performance assessment and management work; what the client's role is concerning these HR practices; how regular the contacts established with the employees are; and how they act when a problem occurs with one of them. During those interviews we were able to ascertain that all four agencies, whose employees participated in the present research, had shared human resource strategies with their clients, being responsible by some training opportunities, having a joint performance assessment and management, performing a crucial role in solving potential problems and establishing regular contacts with these long-term contracted workers.

Concerning data collection almost all employees of these agencies were invited to fill in confidential questionnaires, either during work or at home, as they preferred. We did not include in this research the contracted workers whose tenures were shorter than 3 months, both at the agency and at their current client. The participants took part in the study voluntarily but were also motivated by the fact that they were told of the importance their opinion had for the study's effectiveness and that a report was to be drawn up based on an overall analysis of the data with suggestions regarding the functioning of the company. Employees provided data on their demographic characteristics, their perception on agency's obligations fulfilment, their perception on client's obligations fulfilment, their job insecurity perception and their employability perception. 


\section{Sample}

A total of 88 white-collar contracted workers participated in this research: 30 were from agency A, 23 from agency B, 21 from agency $\mathrm{C}$ and 14 from agency D. There were delivered 126 questionnaires, meaning that the overall response rate represented $69.84 \%$ of the total employees. All of the respondents worked in the client organization's premises. Being all white-collar employees, $17.05 \%$ of them worked in the financial sector and $82.95 \%$ in the information technologies sector. Average mean age was 31 years and $56.8 \%$ of the respondents were male. Concerning education $2.3 \%$ had finished the $9^{\text {th }}$ grade; $4.5 \%$ had quit school between $9^{\text {th }}$ and $12^{\text {th }}$ grade; $25 \%$ had finished the secondary school (12 $2^{\text {th }}$ grade $) ; 63.7 \%$ had been to college or hold a college degree and $4.5 \%$ hold a post-graduate degree. The average tenure in the agency was 1 year and 8 months.

\section{Measures}

Fulfilment of agency's obligations: The employee's perception of the fulfilment of agency's obligations was assessed using a 5 item list of employer obligations. Respondents were asked to indicate how well their agency had been fulfilling its obligations. This is a global psychological contract fulfilment measure similar to what has been widely used in the literature (Rousseau, 1990; Robinson, Kraatz \& Rousseau, 1994; Robinson \& Rousseau, 1994; Robinson \& Morrison, 1995; Coyle-Shapiro \& Kessler, 2002). Respondents were asked to consider their relationship with their current employing agency and to identify if it had fulfilled the following obligations towards them. Items were scored on a five-point Likert scale, ranging from has been fulfilling much less than what it had promised (1) to has been fulfilling much more than what it had promised (5). High scores on this scale indicate high levels of agency's obligations fulfilment (e.g. Give me developmental opportunities within this firm). The $\alpha$ coefficient for this five point Likert scale was .80 .

Fulfilment of client's obligations: A similar scale was used to measure the fulfilment of client's obligations. However three items were erased, namely Give me opportunities for promotion, Concern for my personal welfare and Offer me a stable wage, which were not appropriate considering the contingent nature of the employment relationship. The items that were erased concerned types of obligations that a client organization could never have, such as the ones related to monetary and social benefits. These items were replaced by three other items, namely Support me in meeting higher goals, Help me develop extremely marketable skills and Give me job assignments that create employment opportunities elsewhere. Equally, items were scored on a five-point Likert scale, ranging from has been fulfilling much less than what it had promised (1) to has been fulfilling much more than what it has promised (5). High scores on this scale indicate high levels of client's obligations fulfilment. The $\alpha$ coefficient for this scale was .82 .

Job Insecurity. Job insecurity was measured using 4 items (De Witte, 2000). Items were scored in a fivepoint Likert scale ranging from 1 (entirely disagree) to 5 (entirely agree). High scores on this scale indicate high levels of job insecurity. The scale includes affective (e.g. I think I might loose my job in the near future) and cognitive items (e.g. I am sure I will loose my job). The $\alpha$ coefficient for this scale was .87 .

Employability. Employability was measured using 4 items (De Witte, 2000). Similarly, items were scored in a five-point Likert scale ranging from 1 (entirely disagree) to 5 (entirely agree). High scores on this scale indicate high levels of perceived employability (e.g. I could easily switch to another employer, if I wanted to). The $\alpha$ coefficient for this scale was .77.

Control Variables. In the data analysis, some variables were controlled in order to rule out alternative explanations for the findings. We controlled for age, since it has been shown that this variable can be related to psychological contract (Cavanaugh \& Noe, 1999; Turnley \& Feldman, 2000). Similarly to other studies (e.g. Robinson \& Morrison, 2000; Chambel \& Castanheira, 2006) we also controlled for agency tenure since there were enough outliers to raise concerns that differences in time spent in the employment relationship may have influenced the results. Age was registered in years and agency tenure was registered in days.

\section{Results}

Information about means, standard deviations and correlations between variables is reported in Table 1 . We have found a strong correlation between the perceived fulfilment of client's obligations and the perceived fulfilment agency's obligations. We have also found that job insecurity and the perceived fulfilment of agency's obligations also have a significant negative correlation.

Table 2 presents the results of the factor analysis of the items capturing agency's obligations perceived fulfilment, client organization's obligations perceived fulfilment, job insecurity and employability. The results yielded a four-factor solution corresponding to these four constructs. This provides support that contracted workers distinguish two perceptions of fulfilment of psychological contracts, one for agency and other for client, thereby supporting Hypothesis 1 .

Hypotheses 2, 3 and 4 were tested using hierarchical multiple regression analysis (Cohen \& Cohen, 1983). Hypothesis 2 predicted that perceived fulfil- 
Table 1. Descriptive statistics and correlation matrix for all variables $(\mathrm{N}=88)$

\begin{tabular}{|c|c|c|c|c|c|c|c|c|}
\hline & M & SD & 1 & 2 & 3 & 4 & 5 & 6 \\
\hline 1. Age & 31.39 & 7.81 & & & & & & \\
\hline 2. Agency Tenure & 653.24 & 792.96 & $.32 * *$ & & & & & \\
\hline \multicolumn{9}{|l|}{ 3. Agency's Obligations } \\
\hline Perceived Fulfilment & 2.22 & .98 & $-.23 *$ & $-.35 * *$ & & & & \\
\hline \multicolumn{9}{|l|}{ 4. Client's Obligations } \\
\hline Perceived Fulfilment & 2.19 & 1.15 & $-.28 *$ & -.14 & $.39 * *$ & & & \\
\hline 5. Job Insecurity & 2.89 & .94 & $.21 *$ & $.28 * *$ & $-.31 * *$ & -.16 & & \\
\hline 6. Employability & 3.26 & .75 & -.08 & -.09 & -.09 & -.05 & -.15 & \\
\hline
\end{tabular}

ment of client's obligations would relate positively to the perceived fulfilment of agency's obligations. In the hierarchical multiple analysis that we have used to test Hypothesis 2, we have entered age and agency tenure in Step 1 and client's obligations perceived fulfilment in Step 2 (Table 3).

As shown in Table 3, this hypothesis is supported $(\beta=.34, \rho<.01)$. In the hierarchical regression analyses that we have used test hypothesis 3 and 4 , we have also entered age and agency tenure in Step 1, but we have entered job insecurity and employability in Step 2. Dependent variables were agency's obligations perceived fulfilment and client's obligations perceived fulfilment. As indicated in Table 4, job insecurity relates negatively to the perceived fulfilment of agency's obligations $(\beta=.23, \rho<.05)$ providing support for Hypothesis 3. Contrary, employability is not significantly related to the perceived fulfilment of client's obligations $(\beta=-.09, n s)$, providing not support for Hypothesis 4 .

\section{Discussion}

The increase in the number of contracted workers in the worldwide workforce, stresses the need to understand the employment relationships they establish, both with their agencies and their client organizations. Despite the reasonable amount of research on employee-agency and employee-client relationships little has been done concerning the way these simultaneous relationships might be related. By using the psychological contract framework, this study attempts to examine two unexplored issues: the perceived fulfilment of

Table 2. Results of factor analysis of study variables

\begin{tabular}{|c|c|c|c|c|}
\hline \multirow[t]{2}{*}{ Items } & \multicolumn{4}{|l|}{ Factor } \\
\hline & $\begin{array}{l}\text { Agency's } \\
\text { Obligations } \\
\text { Perceived } \\
\text { Fulfilment }\end{array}$ & $\begin{array}{l}\text { Client's } \\
\text { Obligations } \\
\text { Perceived } \\
\text { Fulfilment }\end{array}$ & Job Insecurity & Employability \\
\hline Help me develop skills that enhance my value inside the firm. & .73 & .29 & -.09 & .01 \\
\hline Give me opportunities for promotion. & .63 & .27 & -.08 & .00 \\
\hline Give me developmental opportunities within this firm. & .71 & .16 & -.34 & -.17 \\
\hline Offer me a stable wage. & .74 & -.08 & -.27 & -.13 \\
\hline Concern for my personal welfare. & .72 & .05 & -.01 & -.02 \\
\hline Help me develop skills that enhance my value inside the firm. & -.05 & .77 & .19 & .04 \\
\hline Support me in meeting higher goals. & .21 & .72 & -.29 & -.01 \\
\hline Give me developmental opportunities within this firm. & .03 & .79 & -.10 & -.18 \\
\hline Help me develop extremely marketable skills. & .24 & .73 & -.12 & .02 \\
\hline Give me job assignments that create employment opportunities & & & & \\
\hline elsewhere. & .34 & .66 & .05 & .03 \\
\hline I am optimistic that I would find another job, if I looked for one. & .03 & -.13 & .11 & .73 \\
\hline I am confident that I could quickly get a similar job. & -.09 & -.12 & -.04 & .77 \\
\hline I will easily find another job if I lose this job. & -.08 & .12 & -.18 & .84 \\
\hline I could easily switch to another employer, if I wanted to. & -.06 & .06 & -.09 & .72 \\
\hline Chances are I will soon loose my job. & -.15 & -.13 & .84 & .07 \\
\hline I am sure I will loose my job. & -.18 & -.04 & .86 & -.00 \\
\hline I feel insecure about the future of my job. & -.05 & -.01 & .73 & -.11 \\
\hline I think I might loose my job in the near future. & -.18 & .00 & .85 & -.19 \\
\hline
\end{tabular}


Table 3. Hierarchical regression analysis examining the relationship between client's obligations perceived fulfilment and agency's obligations perceived fulfilment

\begin{tabular}{|c|c|c|}
\hline \multirow[b]{2}{*}{ Predictors } & \multicolumn{2}{|c|}{ Agency's Obligations Perceived Fulfilment } \\
\hline & Step 1 & Step 2 \\
\hline Age & -.14 & -.05 \\
\hline Agency Tenure & $-.30 *$ & $-.28 *$ \\
\hline Client's Obligations Perceived Fulfilment & & $.34 * *$ \\
\hline Overall F & $5.53 * *$ & $7.37 * * *$ \\
\hline$\Delta \mathrm{R}^{2}$ & $.14 * *$ & $.11 * *$ \\
\hline Adjusted R² & .11 & .21 \\
\hline
\end{tabular}

agency's obligations and the perceived fulfilment of client's obligations.

Relying on the psychological contract theory we found that the perceived fulfilment of agency's obligations and the perceived fulfilment of client organization's obligations are different constructs. This finding reinforces the idea that social exchange and the norm of reciprocity may underpin both intra-organizational and inter-organizational relationships (Coyle-Shapiro \& Morrow, 2006). One might ascertain that contingent workers establish a contract with their agency, so they develop the idea that this organization has a set of obligations towards them and they are constantly assessing if it is fulfilling them or not. Simultaneously, since these workers stay for a certain period of time at the premises of a client organization they also develop the idea that it also has obligations towards them, which can or cannot be fulfilled (McLean Parks, Kidder \& Gallagher, 1998; Druker \& Stanworth, 2004; Claes, 2005).

We have also found that the perceived fulfilment of client's obligations is positively related to the perceived fulfilment of agency's obligations. The main statement that can be drawn from this evidence is the fact that the psychological contracts established between contracted workers and their agencies must not be approached alone, since they are intrinsically related to the psychological contracts they establish with the client organizations where they work. These results converge with the idea of a triangular employment relationship that emerges from contingent employment (McLean Parks, Kidder \& Gallagher, 1998; Davidov, 2004; Druker \& Stanworth, 2004; Claes, 2005). In terms of practical implications, these findings support the idea that agencies who seek to increase their business are supposed to familiarize themselves with dual psychological contracts, finding a way to implement strategies where the client organization is seen as a partner and not an adversary (CoyleShapiro \& Morrow, 2006). These organizations should then be able to share effectively their responsibilities concerning human resource practices, meaning that agencies should define management strategies with each client organization based on the assessment of these webs of mutual expectations (Druker \& Stanworth, 2004).

This study also bears testimony to the assertion that job insecurity is negatively related to employees' perceived fulfilment of agency's obligations. Accordingly to Lee and Faller (2005), agencies are mainly concerned with the structuring of optimal contracts, both with staff and client organizations, in order to guarantee their satisfaction and retention. Despite knowing that their relationships will probably have a limited

Table 4. Hierarchical regression analysis examining the relationship between job insecurity and employability and agency's and client's obligations perceived fulfilment

\begin{tabular}{|c|c|c|c|c|}
\hline \multirow[b]{2}{*}{ Predictors } & \multicolumn{2}{|c|}{ Agency's Obligations Perceived Fulfilment } & \multicolumn{2}{|c|}{ Client's Obligations Perceived Fulfilment } \\
\hline & Step1 & Step 2 & Step 1 & Step2 \\
\hline Age & -.13 & -.10 & -.26 & $-.25^{*}$ \\
\hline Agency Tenure & $-.31 * *$ & $-.26 *$ & -.06 & -.04 \\
\hline Job Insecurity & $-.23^{*}$ & -.11 & & \\
\hline Employability & -.16 & -.09 & & \\
\hline Overall F & $6.69 * *$ & $5.21 * * *$ & 3.05 & 1.83 \\
\hline$\Delta \mathrm{R}^{2}$ & $.14 * *$ & $.07 *$ & .08 & .02 \\
\hline Adjusted $\mathrm{R}^{2}$ & .12 & .16 & .05 & .04 \\
\hline
\end{tabular}


duration, contracted workers may still interpret the fulfilment of agency's obligations as a security indicator. Contracted workers probably consider that the agency has the obligation of placing them with another client whenever a previous project in a client ends, which may give them an illusory feeling of security. As shown by these findings, employee's perceptions of job insecurity can be a threat to this employment relationship, since they will assume that the agency is not fulfilling its obligations (some of these obligations could give him an illusory feeling of job security). These findings are reinforced by the significant correlation between long agency tenure and job insecurity and its significant negative correlation to the perceived fulfilment of agency's obligations. These correlations are quite interesting, since they might be due to the fact that the longer a person stays with an agency, the higher his/her perceived organizational obligations are, including the obligation of providing him/her some security. Due to the contingent nature of their jobs, contracted employees might perceive bigger job insecurity and the non-fulfilment of certain organizational obligations. These findings have implications for human resource professionals, since they should be concerned with and exert effort to avoid creating a psychological contract for job security (King, 2000). It is important that a good professional relationship is created with the contracted workers, but never should promises be made (explicit or implicit) that the agency cannot fulfil. In a joint effort with client organizations, agencies also need to develop their skills on managing the insecure workforce they are dealing with. These management strategies could include specific training for career self-management, and encouragement for workers to learn transferable skills which will increase their employability (Smithson and Lewis, 2000).

Our fourth hypothesis was not supported by the results. Accordingly, the perception of employability was not significantly related to the perceived fulfilment of client's obligations. Although the development of employability may be considered a new form of job security (Bagshaw, 1997), we may suppose that contracted workers do not see it as an obligation on the part of the client, but as something that is up to them. Based on this assumption, employability will not have a significant positive relationship with the perceived fulfilment of client's obligations, even though literature on employability and on psychological contract gives us the tools to suppose so.

\section{Limitations and Future Research}

The present research has a number of limitations that need to be recognized. Firstly, this study was carried out at a moment in time (cross-sectional design) and with a correlational design. This means that not only were we unable to rule out relationships based on causality but also to empirically demonstrate our causal inferences. Longitudinal studies are needed for the assessment of these causal relations. Nevertheless the problem of high turnover among the contingent workforce may hamper the realization of a longitudinal design. Secondly, another possible limitation of this research may be the small sample size, which can be a negative aspect, considering the generalization of the results. However, small sample is not a very uncommon issue concerning the contingent employment research (Benson, 1998; Liden, Wayne, Kraimer \& Sparrowe, 2003; Claes, 2005; Coyle-Shapiro \& Morrow, 2006). The biggest problem of the small sample size is the decreased precision in estimates. This limitation is however not that significant, since to use multiple regression analysis the ratio of observations to independent variables should not fall below five (Hair, Anderson, Tatham, \& Black, 1995) and in our case it is largely superior. Furthermore, our data relies on self-reports, which can increase the risks of inflated relationships as a result of respondents tendencies to respond in a consistent manner. However more recent meta-analytic research on the percept-percept inflation issue indicates that the magnitude of the inflation of the relationships may be over-estimated (Crampton \& Wagner, 1994). Another limitation of this investigation relies on the fact that, although all the agencies had a shared human resource management with the client organizations, the practices shared by each one of them were not completely homogeneous, which could have somehow affected our results. Finally, we must also regard as a limitation the fact that this research only includes contracted workers who work in two activity sectors: the financial and the information technology sectors. Then this study should be enlarged to other sectors in order to amplify the generalization of the results.

Future research is needed to replicate and extend these findings. Additional research is needed to explore workers' psychological contract with the agency, workers' psychological contract with the client organization and the mechanisms that may connect these two relationships. Future research could focus on a better understanding of human resource practices shared by the agency and the client organization, in order to assess how some particular HR practices affect, both the psychological contract fulfilment and content towards the agency and the client. It would also be relevant to assess which are the attributions that contracted workers make of the hidden reasons behind the HR practices (Nishii, Lepak \& Schneider, 2008). One could also assess if perceived fulfilment of agency's and client's obligations are affected by employee's commitment towards both of them and by the perceived organizational support they receive from both of them. Another interesting item to explore would be the effect of the notion of employability on the perceived fulfilment of agency's obligations, using 
a boundaryless sample. Using that kind of sample, one should also evaluate agency and client attractiveness.

\section{Conclusion}

Social exchange theory has been approached as a major guideline to study employee organization relationships (Blau, 1964). Relying on this framework, the psychological contract theory provides a solid basis for the assessment of the emerging contingent employment relationships. The web of mutual expectations created by contingent employment (Druker \& Stanworth, 2004) adds a particular relevance to the study of these relationships. The results of our research indicate that it is crucial that human resource practitioners focus on the dual psychological contracts established by contracted workers towards both their agencies and the client organizations where they work. Human resource practitioners from the agency and from the client should meet regularly and discuss HR practices such as training and performance management, in order to define the best ways to manage these employees. Agency representatives should also frequently meet with the employees and focus on their career paths, more specifically on how working for that client can be a career advantage or not. This concern with employees' careers is quite important since human capital is regarded as the most relevant for an agency and retention means placing the employees with good clients.

It is also extremely relevant to understand that job insecurity, which is inherent to contingent employment, still relates negatively to the perceived fulfilment of agency's obligations. This means that, although job insecurity should already be expected by contracted workers, it still may have a negative impact on their employment relationships. Human resource practitioners need to be particularly careful in order not to create false security expectations on their employees. Considering the enormous growth of contingent employment relationships, both in Portugal and worldwide, the need for additional research on these relationships has to be emphasized, especially through the serious consideration of the psychological contract theory. Future research should always have a practical perspective and focus on human resource management practices, especially on the potential benefits of a shared human resource management and on the way employees understand the meanings of these practices.

\section{References}

Anderson, N., \& Schalk, R. (1998). The psychological contract in retrospect and prospect. Journal of Organizational Behaviour, 19, 637-647.
Arrowsmith, J. (2006). Temporary agency work in an enlarged European Union [electronic version]. Retrieved from the European Foundation for the Improvement of Living and Working Conditions Website: www.eurofound .eu.int.

Bagshaw, M. (1997). Employability - Creating a contract of mutual investment. Industrial and Commercial Training, 29, 187-189.

Baruch, Y. (2001). Employability: A substitute for loyalty? Human Resource Development International, 543-566.

Benson, J. (1998). Dual Commitment: Contract workers in Australian manufacturing enterprises. Journal of Management Studies, 35, 355-375.

Blau, P. (1964). Exchange and Power in Social Life. New York: Wiley.

Cavanaugh, M. A., \& Noe, R. A. (1999). Antecedents and consequences of relational components of the new psychological contract. Journal of Organizational Behaviour, 20, 323-340.

Chambel, M. J., \& Castanheira, F. (2006). Different temporary work status, different behaviors in organization. Journal of Business and Psychology, 20, 352-367.

CIETT (2009). The agency work industry around the world [electronic version]. Retrieved April 20, 2009 from www.euro-ciett.org

Claes, R. (2005). Organization promises in the triangular psychological contract as perceived by temporary agency workers, agencies, and client organizations. Employee Responsibilities and Rights Journal, 17, 131-142.

Cohen, J., \& Cohen, P. (1983). Applied Multiple Regression / Correlation Analysis for the Behavioral Sciences. $\left(2^{\text {nd }}\right.$ edition). Erlbaum: Hillsdale NJ.

Connelly, C. E., \& Gallagher, D. G. (2004). Emerging trends in contingent work research. Journal of Management, 30, 959-983.

Coyle-Shapiro, J. A. (2002). A psychological contract perspective on organizational citizenship behaviour. Journal of Organizational Behavior, 23, 927-946.

Coyle-Shapiro, J. \& Kessler, I. (2002) Reciprocity through the lens of the psychological contract: Employee and Employer perspectives. European Journal of Work and Organizational Psychology, 11, 1-18.

Coyle-Shapiro, J., \& Morrow, P. (2006). Organizational and client commitment among contracted employees. Journal of Vocational Behavior, 68, 416-431.

Crampton, S. M., \& Wagner, J. A. (1994). Percept-percept inflation in microorganizational research: An investigation of prevalence and effect. Journal of Applied Psychology, 79, 67-76.

Davidov, G. (2004). Joint employer status in triangular employment relationships. British Journal of Industrial Relations, 42, 727-746.

De Cuyper, N., \& De Witte, H. (2006). The impact of job insecurity and contract type on attitudes, well-being and behavioural reports: A psychological contract perspective. Journal of Occupational and Organizational Psychology, 79, 395-409.

De Cuyper, N., \& De Witte, H. (2007). Job insecurity in tem- 
porary versus permanent workers: Associations with attitudes, well-being, and behaviour. Work and Stress, 21, 65-84.

De Cuyper, N., de Jong, J., De Witte, H., Isaksson, K., Rigotti, T., \& Schalk, R. (2008). Literature review of theory and research on the psychological impact of temporary employment: Towards a conceptual model. International Journal of Management Reviews, 10, 25-51.

De Cuyper, N., Notelaers, G., \& De Witte, H. (2009). Job insecurity and employability in fixed-term contractors, agency workers, and permanent workers: Associations with job satisfaction and affective organizational commitment. Journal of Occupational Health Psychology, 14, 193-205

De Witte, H. (1999). Job insecurity and psychological wellbeing: review of the literature and exploration of some unresolved issues. European Journal of Work and Organizational Psychology, 8, 155-177.

De Witte, H. (2000). Arbeidsethos en jobonzekerheid: meting en gevolgen voor welzijn, tevredenheid en inzet op het werk [Work ethic and job insecurity: Measurement and consequences for well-being, satisfaction and performance]. In R. Bouwen, K. De Witte, H. De Witte, T. Taillieu (Eds.), Van groep naar gemeenschap. Liber Amicorum Prof. Dr. Leo Lagrou. Leuven: Garant, 352350.

Druker, J., \& Stanworth, C. (2004). Mutual expectations: A study of the three-way relationship between employment agencies, their client organisations and white-collar agency temps. Industrial Relations Journal, 35, 58-75.

Feldman, D. C. (2005). Toward a new taxonomy for understanding the nature and consequences of contingent employment. Career Development International, 11, 2847.

Forrier, A., \& Sels, L. (2003). Temporary employment and employability: Training opportunities and efforts of temporary and permanent employees in Belgium. Work, Employment and Society, 17, 641-666.

Gouldner, A. W. (1960). The norm of reciprocity. American Sociological Review, 25, 161-178.

Hair, J., Anderson, R., Tatham, R., \& Black, W. (1995). Multivariate data analysis ( $4^{\text {th }}$ ed.). Upper Saddle River, NJ: Prentice Hall.

Instituto de Emprego e Formação Profissional (2009). Empresas de trabalho temporário licenciadas [electronic version]. Retrieved April 20, 2009 from http://www. iefp.pt.

Kalleberg, A. L., Reskin, B. F., \& Hudson, K. (2000). Bad jobs in America: Standard and non-standard employment relations and job quality in the United States. American Sociological Review, 65, 256-278.

King, J. E. (2000). White-collar reactions to job insecurity and the role of the psychological contract: Implications for human resource management. Human Resource Management, 39, 79-92.

Kluytmans, F., \& Ott, M. (1999). Management of employability in The Netherlands. European Journal of Work and Organizational Psychology, 8, 261-272.
Lee, G. (2001). Towards a contingent model of key staff retention: The new psychological contract reconsidered. South African Journal of Business Management, 32, 1-9.

Lee, G. J., \& Faller, N. (2005). Transactional and relational aspects of the psychological contracts of temporary workers. South African Journal of Psychology, 35, 831-847.

Lepak, D. P., Takeuchi, R., \& Snell, S. A. (2003). Employment flexibility and firm performance: Examining the interaction effects of employment mode, environmental dynamism, and technological intensity. Journal of Management, 29, 681-703.

Liden, R. C., Wayne, S. J., Kraimer, M. L., \& Sparrowe, R. T. (2003). The dual commitments of contingent workers: an examination of contingents' commitment to the agency and the organization. Journal of Organizational Behavior, 24, 609-625.

McLean Parks, J., Kidder, D. L., \& Gallagher, D. G. (1998). Fitting square pegs into round holes: Mapping the domain of contingent work arrangements onto the psychological contract. Journal of Organizational Behavior, 19, 697730 .

Marler, J. H., Barringer, M. W., \& Milkovich, G. T. (2002). Boundaryless and traditional contingent employees: worlds apart. Journal of Organizational Behavior, 23, 425-453.

Moorman, R. H., \& Harland, L. K. (2002). Temporary employees as good citizens: Factors influencing their OCB performance. Journal of Business and Psychology, 17, 171-187.

Nishii, L. H., Lepak, D. P., \& Schneider, B. (2008). Employee attributions of the "why" of HR practices: their effects on employee attitudes and behaviours, and costumer satisfaction. Personnel Psychology, 61, 503-545.

Robinson, S. L., Kraatz, M. S., \& Rousseau, D. M. (1994). Changing obligations and the psychological contract: A longitudinal study. Academy of Management Journal, 37, 137-152.

Robinson, S. L., \& Rousseau, D. M. (1994). Violating the psychological contract: Not the exception but the norm. Journal of Organizational Behavior, 15, 245-259.

Robinson, S. L., \& Morrison, E. W. (1995). Psychological contracts and OCB: The effect of unfulfilled obligations on civic virtue behaviour. Journal of Organizational Behavior, 16, 289-298.

Robinson, S. L., \& Morrison, E. W. (2000). The development of psychological contract breach and violation: a longitudinal study. Journal of Organizational Behavior, 21, 525-546.

Rousseau, D. M. (1989). Psychological and implied contracts in organizations. Employee Responsibilities and Rights Journal, 2, 121-139.

Rousseau, D. M. (1990). New hire perceptions of their own and their employer's obligations: A study of psychological contracts. Journal of Organizational Behavior, 11, 389-400.

Rousseau, D. M. (2004). Psychological contracts in the workplace: Understanding the ties that motivate. Academy of Management Executive, 18, 120-127. 
Smithson, J., \& Lewis, S. (2000). Is job insecurity changing the psychological contract? Personnel Review, 29, 580702 .

Sverke, M., Gallagher, D. G., \& Hellgren, J. (2000). Alternative work arrangements: Job stress, well-being, and work attitudes among employees with different employment contracts. In K. Isaksson, L. Hogsted, C. Eriksson, \& Theorell (Eds.), Health effects of the new labour market (pp. 145-167). New York: Plenum Press.

Theodore, N., \& Mehta, C. (1999). Contingent work and the staffing industry: A Review of worker-centered policy and practice. Chicago, IL: Center for Urban Economic Development, University of Illinois at Chicago.

Turnley, W. H., \& Feldman, D. C. (2000). Re-examining the effects of psychological contract violations: Unmet expectations and job dissatisfaction as mediators. Journal of Organizational Behaviour, 21, 25-42.

Van Vuuren, T., Klandermans, B., Jacobson, D., \& Hartley, J. (1991). Employees' reactions to job insecurity. In J. Hartley, D. Jacobson, B. Klandermans, and T. van Vuuren, Job Insecurity: Coping with jobs at risk (pp. 79103). London: Sage.

Manuscrito recibido: 30/6/2009

Revision recibida: $15 / 9 / 2009$

Aceptado: 19/9/2009 